\title{
THE FREE MOVEMENT OF ECONOMICALLY INACTIVE EU CITIZENS: THE RIGHT TO RESIDE TEST
}

\author{
Laura Gyeney \\ Péter Pázmány Catholic University, Faculty of Law and Political Sciences
}

\begin{abstract}
The question of free movement rights of economically inactive citizens and their access to social assistance is a legally controversial and a politically sensitive issue. This is well illustrated by the CJEU's recent case law which signals a shift in its former jurisprudence towards a more restrictive approach relating to access to social assistance benefits for economically inactive EU citizens. Moreover, the Court's case law appears to be moving away from the concept of EU citizenship as a general value and common solidarity. The present article aims to give a brief overview of the relevant case law with the aim of seeking answer the question whether this turn in the CJEU's case law predicts a real paradigm shift or just a consolidation phase in the Court's jurisprudence.
\end{abstract}

Keywords: free movement, union citizenship, economically inactive citizens, social assistance, social security, solidarity, principle of proportionality

\section{INTRODUCTION}

The EU institutions are forced ever more often to protect the fundamental principle of free movement of European citizens from political and legal attacks. The citizens' right are contested both politically and legally. First, it is questioned politically in several member states, mainly due to its alleged impact on the welfare state. The question of welfare benefits became "one of the hottest political topics in the public debate prior to the Brexit referendum" ${ }^{1}$. The ongoing debate on free movement focuses on the access of economically active EU citizens to social benefits. Nothing illustrates this better than the political statements - sometimes taking a threatening tone - aiming to vigorously cut back the entitlements associated with free movement. For example let us take the claim of the former British Prime Minister David Cameron that foreigners working in the UK should only be able to access the British social assistance system after four years of continuous residence and employment. Current political statements also suggest that the UK will not mince its words when it comes to its future immigration policy, so free movement of workers from the EU will no longer apply. But it is not only the British who are sceptical. The German and Austrian governments also promised to reduce incentives for migration and take steps towards reducing benefits by adopting more restrictive laws. This is well illustrated by the fact that the new Austrian government intends to cut family benefits for workers whose children live abroad, a decision that would mostly affect employees from Central European countries such as Poland, Slovakia and Hungary. The Visegrád countries, with Poland the leading way, on the other hand, take the opposite and express a clear

1 THYM, D. The judicial deconstruction of Union citizenship. In THYM, D. (ed): Questioning EU citizenship. Judges and the limits of free movement and solidarity in the EU. Oxford : Hart Publishing, 2017, p. 2. 
commitment to the principle of free movement "promising strong support for a cornerstone of EU integration".

The current political climate however, has also had an impact on the Court's recent jurisprudence in respect of economically inactive citizens. In the last few years, the European Court of Justice has increasingly faced with the question whether economically inactive EU citizens are also entitled to claim social assistance and special non-contributory benefits.

From 2013 to 2016 five important ECJ judgments have been delivered on this topic in the Brey, Dano, Alimanovic, Garcia Nieto and Commission v UK cases which all deal with the limits of social solidarity to which mobile EU citizens are entitled. The above cases apparently signal a shift in the CJEU's former jurisprudence towards a restrictive approach relating to access to social assistance benefits for economically inactive EU citizens. While the Court in its classic jurisprudence on citizenship has been "the most vocal actor in stretching the right to free movement in both depth and breadth, also against member states' preferences", now it seems to have reconsidered its former approach on free movement, increasingly yielding to the Member states' discretion to protect their public finances. In some authors' view this predicts "a narrow type of solidarity being promoted in the EU", since it is available only for those who do not really need it. Furthermore, some argue that the new case law "destroys any residual hopes that citizens might have equal treatment rights stemming from EU citizenship". Is this really the case?

In the following we give a brief overview of the case law concerned with the entitlement of economically inactive EU citizens to social rights in their host states, first with the aim of seeking answer the question whether the change in the CJEU's case law relating to access to social benefits for economically inactive citizens is as drastic as it is argued above - or is this just a consolidation phase in the Court's jurisprudence without any real paradigm shift.

Secondly, we make an attempt to reveal the underlying reasons behind these changes in the CJEU's interpretation of the free movement directive. However, before turning to the analysis of the case law it is useful to provide a short summary of the free movement regime in the EU.

\section{THE FREE MOVEMENT REGIME UNDER DIRECTIVE 2004/38}

Before all, we must establish that free movement has never been a right for everyone and has always been conditional. Directive 2004/38 on the right of citizens of the Union and their family members to move and reside freely within the territory of the member states ${ }^{3}$ (hereinafter free movement directive) makes a distinction between economically active and inactive persons. For residence longer than three months, economically inactive EU citizens must have sufficient resources in order not to become an unreasonable burden on the social assistance system on the host member state during their period of residence and have comprehensive sickness insurance.

However, this piece of legislation contains uncertain notions such as the requirements of "unreasonable burden" or "sufficient resources" ${ }^{4}$ Instead of giving specific guidelines, it prescribes a case

2 Ibid.

3 Commission Directive 2004/38 on the right of citizens of the Union and their family members to move and reside freely within the territory of the Member states OJ L 158, 30. 4. 2004, p. 77-123.

4 Dir. Artivle 7(1)b. 
by case analysis by the national authorities. ${ }^{5}$ Thus, it is unclear when an EU citizen becomes an "unreasonable burden" to the social assistance system. The confusion gets even deeper looking at the provision of the Directive according to which an expulsion measure shall not be the automatic consequence of a EU citizen's or his or her family member's recourse to the social assistance system of the host Member state. ${ }^{6}$

This inherent tension in the free movement regime provokes debate: while, in order to prevent an unreasonable burden on the social assistance systems of the Member states, self sufficiency is demanded as a residence condition; not possessing sufficient resources does not necessarily mean losing one's right to residence and to equal treatment, rather a proportionality test is ultimately decisive. This tension also brings legal uncertainty into the free movement regime - a situation for which not only the Court's jurisprudence on EU citizenship may be blamed, but also the Union legislator having transformed it into indeterminate provisions of secondary law. ${ }^{7}$

In any case, it poses a challenge for determining free movement and equal treatment rights of not economically active actors under the current EU rules. ${ }^{8}$ The challenge is to find a balance between the requirement to fulfil the condition of sufficient resources and the possibility to apply for social assistance, as it is clearly demonstrated by the Court's recent jurisprudence presented below.

\section{THE CJEU' S RECENT JURISPRUDENCE ON ENTITLEMENT OF EU CITIZENS TO SOCIAL RIGHTS}

\subsection{The Brey case}

The Court's change of trend began in 2010 with the Brey ruling. In this case, the European Court of Justice had to interpret EU law as regards to the application for compensatory supplement of a retired couple. The Brey case concerned a German couple that moved from their home country to Austria in 2011 in order to reside there. Mr Brey had an $862 €$ pension in Germany. Given that the couple did not have any other income or assets, they applied for compensatory supplement, the granting of which was made conditional by the Austrian authorities upon fulfilling the requirements for the right to residence. The German couple had to prove that their residence fulfilled the requirements set out in the free movement directive and that they did not place an unreasonable burden on the social assistance system of Austria.

\footnotetext{
Dir. Article 8(4).

Dir. Article 14(3).

The "voluntarily obscure phrasing" which was presumably some sort of a compromise during the drafting of the legislation - comes at a price. That price is the burden on those who enforce the law to define in which cases a claim for social assistance means that the economically inactive person has the necessary sources for their lawful residence without putting an unreasonable burden on the social assistance system of the host country. THYM, D. The elusive limit of solidarity: residence rights of and social benefits for economically inactive Union Citizens. In Common Market Law Review. Vol. 52, No.1 (2017), p.18.

8 According to some views it would be much clearer if the provisions of the Directive excluded economically inactive EU citizens from all social assistance, moreover, social benefits until they obtain their long-term residence status. VERSCHUEREN, H. Preventing benefit tourism in the EU. A narrow or broad interpretation of the possibilities offered by the ECJ in Dano? In Common Market Law Review. Vol. 52, No.2 (2015), p. 381.
} 
The Austrian authorities however refused to grant this benefit because in their view, Mr Brey did not meet the conditions required to obtain the right to reside as he lacked sufficient resources.

In its Brey decision the CJEU emphazised that the fact that an economically inactive citizen from another member state may be eligible, in the light of a low pension, to receive that benefit, could be an indication that the national in question does not have sufficient resources to avoid becoming an unreasonable burden on the social assistance system of the host Member states. ${ }^{9}$ At this pont however, it is important to stress that "we are only in the presence of an indication, not of an established fact" ${ }^{10}$ and that - as it is clearly pointed out by the Court ${ }^{11}$ - any limitation upon the free movement must be construed in compliance with the principle of proportionality. According to the Court' reasoning denial always requires a prior assessement of the claimant's individual circumstances and such an automatic character of the refusal- which characterised the specific case- prevents the national authorities from carrying out that test.

It was also emphasised by the Court that the member states'margin for manoeuvre may not be used in such a manner as to compromise the attainment of the objective of Directive 2004/38, more specifically to facilitate and strengthen the primary right to free movement. ${ }^{12}$

At first sight, the Court maintained a protective approach towards the rights of the non- economically active claimant as it applied a purposive interpretation of the norms of the directive ensuring rights to union citizens. Recognising the discrepancy of the directive, it explicitly highlighted the necessity of the "effet utile" of the provisions therein and of the strict interpretation of the restrictions on free movement. ${ }^{13}$

However, it also made clear that nothing prevents member states from subjecting the eligibility of inactive citizens for social benefits to a test of legal residence. ${ }^{14}$ This statement, while arguably wellsupported in EU Treaty and secondary law, demonstrated a first important concession to member states' discretion.

In the following cases the Court went further in recognising a margin of discretion to the member states in excluding an economically active European citizen.

\subsection{The Dano case}

The Dano case concerned two Romanian citizens living on benefits in Germany, without ever having worked or studied in the host member state. At the end of 2010, Ms Dano moved to Germany, to her sister who provided them with food and lodging. The documentation reveals that Ms Dano did not enter Germany in order to look for work nor was she actively seeking work in that country. Despite all this, she approached the Leipzig Jobcenter claiming basic social assistance benefit for jobseekers. The authority refused this claim by reference to the limitation contained in the German legislation that is specifically aimed at those who come to the country solely in order to benefit from the social assistance scheme. The case came before the European Court of Justice for preliminary ruling. In

Brey judgment para 63.

10 MINDERHOUD, P., MANTU, S. Access to social assistance, op. cit., p. 197.

11 Brey judgment para 64.

12 Ibid., para 71.

13 VERSCHUEREN, H. Free movement of benefit tourism. The Unreasonable burden of Brey. In European Journal of Migration and Law. Vol.16, No.2 (2016), p. 158; Brey judgment para 65 - 71

14 Brey judgment para 44. 
its judgment, the CJEU after having declared that the benefits in question are social assistance, established a very important thesis: if the economically inactive citizens, such as Dano, do not engage in any professional occupation, neither are they looking for employment, so far as access to social benefits is concerned, they can only claim equal treatment with nationals of the host member state if their residence in the territory of the host member state is lawful, and complies with the conditions of Directive 2004/38. ${ }^{15}$ This is in full compliance with the wording of the equal treatment clause ${ }^{16}$ of the Directive which states that Union citizens who reside on the basis of the Directive -that is it fulfil the conditions described above- enjoy equal treatment with nationals of the host member states within the scope of the Treaty.

Thus, the question was whether Ms Dano complied with the requirements set out in the Directive.The citizens in the case, Ms Dano and her son - at least according to the referring court - did not meet that requirement laid down in the directive as they lacked sufficient resources pursuant to Article 7(1)(b) of the directive. In accordance with the decision of the CJEU, they were therefore not entitled to a right of residence in Germany, nor were they entitled to claim equal treatment and so the benefit in question. In brief, the Court ruled that unequal treatment was an inevitable consequence' of the EU rules. ${ }^{17}$

As we saw, the initial jurisprudence of the CJEU and its subsequent codification in the free movement directive have introduced a certain flexibility regarding the application of the economic criteria. The above mentioned Brey case constitutes a recent example of this approach. If in Brey applying for a benefit was "only an indication of lack of sufficient resources, in Dano has become certainty" ${ }^{18}$ What is more, in the Dano case the Court did not even make a mention about the test of proportionality set out in the directive and its previous case law. The CJEU's ruling seems to reflect a strict reading of the economic residence criteria, it does not discuss any relativisation in view of proportionality requirements. Moreover, it emphasises the Directive's goal to protect the social system of the host member state. Unfortunately, the Court did not explain the circumstances under which the application of the proportionality test was set aside.

It can be assumed however, that the absence of social integration could play an important role in the outcome of the Dano case. This point is confirmed by CJEU's case law that is increasingly emphasising the requirement of social integration in the field of free movement. In its jurisprudence concerning economically inactive citizens and job seekers, the Court has been applying for nearly one and a half decades the requirement of a "real link"19 and of a "certain degree of integration" ${ }^{20}$ as the objective norm to justify the derogation from equal treatment. ${ }^{21}$ Moreover, the test of integration/real link is not only applied in relation to economically inactive citizens anymore. In the Court's most recent jurisprudence concerning free movement it is used generally, as guidance in every case with regards to the interpretation of the principle of non-discrimination.

15 Dano judgment para 68.

16 Directive Art. 24(1).

17 Dano judgment para $77-78$

18 MINDERHOUD, P., MANTU, S. Access to social assistance, op. cit., p. 199.

19 C- 224/98, D’Hoop v Office national de lemploi, ECLI:EU:C:2002:432, para 38.; C- 138/02, Collins v Secretary of State for Work and Pensions, ECLI:EU:C:2004:172, para 67.

20 C- 209/03, Dany Bidar v London Borough of Ealing and Secretary of State for Edu, ECLI:EU:C:2005:169, para 57.

21 MANTU, S., MINDERHOUD, P. Solidarity (still) in the making or bridge too far? In Nijmegen Migration Law Working Papers Series. Vol.1 (2015), p. 20. 
With particular regard to the Court's decisions concerning the granting of permanent residence permit $^{22}$ and the application of the exception concerning public order /public security/expulsion ${ }^{23}$, a significant shift can be observed from the "equal treatment as an instrument of integration" model towards the "rights granted according to the degree of social integration" approach. ${ }^{24}$

This concept is also reflected in Directive 2004/38/EC itself, insofar as it promotes a "gradual system" for equal treatment and protection against expulsion, including through permanent residence status with wide-ranging guarantees after five years of lawful residence. ${ }^{25}$

\subsection{The Alimanovic case}

In the Alimanovic decision that followed the Dano judgment and was similar to it in subject matter, the Court referred expressis verbis to the „gradual system” of retaining the worker status established by the Free Movement Directive as the basis of its decision. According to the Court's judgment that system seeks to safeguard the right of residence and access to social assistance by taking into consideration itself the various factors characterising the individual situation of each applicant for social assistance. ${ }^{26}$

The Alimanovic case concerned a Swedish woman and her daughter who had worked in Germany briefly, then lost their jobs. They applied for a special benefit in Germany, and the national court asked the CJEU if they were entitled to it.

To decide whether they had access to those benefits, the Court - as in the case of its former Dano judgment- interpreted the equal treatment rule of the Directive ${ }^{27}$ which states that equal treatment applies to all those EU citizens 'residing on the basis of this Directive' and their family members. ${ }^{28}$ Having thoroughly examined the question, the Court however established that the applicants no longer enjoyed their former worker status under the Directive by the time they were refused entitlement to the benefits at issue. ${ }^{29}$ Article $7(3)(c)$ of the Directive says ${ }^{30}$ that those who work in the host State for less than one year - as in their case- retain 'worker' status for at least six months after becoming unemployed. After that point, a member state can terminate their worker status, which means they are no longer covered by the equal treatment rule. In this case they can be classified un-

22 “...the integration objective which lies behind the acquisition of the right of permanent residence laid down in Article 16(1) of Directive 2004/38 is based not only on territorial and time factors but also on qualitative elements, relating to the level of integration in the host Member state." C- 325/09, Secretary of State for Work and Pensions v Maria Dias, ECLI:EU:C:2011:498, para 64.

23 C- 145/09, Land Baden-Württemberg v Panagiotis Tsakouridis, ECLI:EU:C:2010:708, C- 348/09 P.I. v Oberbürgermeisterin der Stadt Remscheid, ECLI:EU:C:2012:300

24 It is possible to distil two potentially opposing approaches to migrant integration policies, the first one concentrating on equal rights as an end in itself irrespective of the actual degree of social integration, while the second approach focuses on social integration as an objective to be achieved and expects the individual to actively pursue incorporation into societal structures. Success or failure of this venture may regulate the degree of residence security and equal treatment under EU law. THYM, D. Legal framework for EU immigration policy. In HAILBRONNER, K., THYM, D. (ed.): EU Immigration and Asylum Law. Commentary. München, Oxford, Baden Baden : C.H. Beck/Hart/Nomos, 2016, p. 291.

25 THYM, D. The elusive limit of solidarity, op. cit., p. 36.

26 Alimanovic judgment para 60.

27 Dir. Art.24.

28 The CJEU thus re-established that only EU nationals who have a right of residence under the Directive are entitled to equal treatment with nationals of the host Member state.

29 Alimanovic judgment para 55.

30 Dir. Article 7(3)(c). 
der Article 14(4)(b) of the Directive as first-time job-seekers. A job-seeker cannot be expelled from that member state for as long as he can provide evidence that he is continuing to seek employment and that he has a genuine chance of being engaged. However, first-time jobseekers are not entitled to social assistance, therefore the host member state may refuse to grant any social assistance. This approach is understandable in light of the wording of the Directive's equal treatment clause and the Court's emphasis on the need for a significant level of legal certainty. ${ }^{31}$

It is interesting however that the Court, similarly to Dano - and contrary to the previous Brey case- did not apply the test of proportionality in this case either. The Court in its reasoning simply states that in the present circumstances no proportionality test in the form of an individual assessment of the person concerned is required. This statement is justified by the above mentioned argument that the citizens' Directive itself already took account of the individual position of workers.

Following its strict findings in the Dano and Alimovic judgments, the Court of Justice of the European Union "could not but state the obvious" ${ }^{32}$ in case García-Nieto and others that is member states may exclude economically inactive EU citizens from social assistance who are residing in the host member state for a period not exceeding three months. Again, the Court opted for legal certainty in severe and explicit terms and stressed the objective of preventing the foreign EU citizen from becoming an unreasonable burden on the host member state's social assistance system.

\subsection{The Garcia Nieto case}

The Garcia Nieto case concerned a Spanish couple with two children. Ms Garcia Nieto moved to Germany in April 2012, and shortly after the mother began working as a kitchen assistant. In June 2012, her unmarried and not registered partner and his son joined the other two in Germany. The family applied for social benefit, which was refused for the father and his son, because at the time of the application they had resided in Germany for less than three months and did not have the status of worker or self-employed person.

The Court upheld its Dano and Alimanovic decisions and reestablished that Union citizens can claim equal treatment under the equal treatment clause of the Directive laid down in Article 24(1) of the Directive only if their residence in the territory of the host member states complies with the conditions of the Directive. The Directive provides that as a general rule Union citizens have the right of residence in the territory of the host member state for a period of up to three months without any conditions. However, in such a case - as it was mentioned above - the host member state may rely on the derogation in Article 24 (2) of the Directive in order to refuse to grant that citizen the social assistance sought. It seems reasonable that EU citizens who move to another Member state can not ask for social assistance during the first three months and Article 24(2) is clear on this. ${ }^{33}$

31 According to Article 24(2) of the Directive EU citizens who move in search of employment can be excluded from social assistance for as long as they are looking for a job, that is the host Member state shall not be obliged to confer entitlement to social assistance during the first three months of residence or, where appropriate, the longer period provided for in Article 14(4)(b).

32 KRAMER, D. Short-term residence, social benefits and the family, an analysis of case C-299/14 (Garcia Nieto and others) [online]. Available at <https://europeanlawblog.eu/tag/c-29914-garcia-nieto-and-others/> [q. 2018-09-12].

33 Despite the judgment's "clear contribution to legal certainty" concerning the application of article 24 (2) to economically inactive EU citizens, the judgment is confusing with respect to the possible status of the father and his son as family members of a worker. Since the Court speaks throughout of a 'family' it is noteworthy that the possible eligibility of the 
The Court in the Garcia Nieto case applies similar logic as in case Alimanovic: although the Directive requires host member states to take account of the individual situation of the EU citizen when it considers one to be a burden on the social assistance system, this is not required in the current situation. Just like the job-seeking EU citizen who lost his/her worker status, the Free Movement Directive itself provides for the economically inactive in their first three months of residence a 'gradual system [...] which seeks to safeguard the right of residence and access to social assistance', taking into consideration 'various factors characterising the individual situation of each applicant for social assistance and, in particular, the duration of the exercise of any economic activity. ${ }^{34}$

As we see the Court in Alimanovic and Garcia Nieto qualified its Brey ruling, holding that, in the case of jobseekers and in the case of migrant Union citizens in the first three months of residence in a host Member state, a claim for social assistance can be automatically denied without further individual assessments. ${ }^{35}$

\subsection{The Commission v. UK case}

The most recent example of giving room to Member states's discretion is the Court's Commission $\mathrm{v}$ UK decision in which the CJEU upheld the UK ordinary residence test for the grant of social benefits to migrant Union citizens.

The Commission had received several complaints about the UK's right to reside test which excludes EU nationals from eligibility for several welfare benefits unless they meet the criteria laid down in the Free Movement Directive. Thus, the UK legislation made the grant of these benefits conditional upon having a right to reside in the UK, in addition to being habitually resident. Unlike the benefits at issue in Brey, Dano, Alimanovic or Garcia Nieto, these benefits are not special non-contributory benefits, which are categorised as social assistance within the meaning of the free movement directive. The benefits at issue, namely child benefit and child tax credit are social security benefits, falling within Regulation $883 / 2004^{36}$ (hereinafter referred as social security coordination regulation). ${ }^{37}$ In short, they must be workers, or have retained worker status, or be the family members of EU national workers.

The Commission had two heads of claim. First, it challenged that the test added a condition that does not appear in the social security coordination regulation. Secondly, it argued that the right to reside test is a form of direct discrimination based on nationality, because EU national claimants must show that they fulfil the conditions of the Directive while UK nationals automatically have a right to reside.

father to social benefits as a family member of an economically active citizen under the Directive is not addressed. See more about this in Kramer.

34 Garcia-Nieto judgment para $46-48$.

35 STRUMIA, F. Chronicles of a Troubled Narrative, op. cit., p. 155.

36 Regulation (EC) No 883/2004 of the European Parliament and of the Council of 29 April 2004 on the coordination of social security systems, OJ L 166, 30. 4. 2004, p.1.

37 As it is emphazised by Steve Peers these benefits "are squarely in the material scope of Regulation 883/2004, and so subject to the equal treatment provision therein." In this way the Regulation offers some protection to the children in migrating families, since they are typically subjects rather than agents of migration, and it has usually been accepted that they should not be penalised for changes in their parents' work status. [online]. Available at $<\mathrm{http} / /$ eulawanalysis. blogspot.com/2016/06/dont-think-of-children-cjeu-approves.html> [q. 2018-09-12]. 
The Court dismissed the action of the Commission. Regarding the first ground the European Court of Justice decided that the Social coordination Regulation is only a conflict of law rule which does not set up a common scheme of social security, but allows different national social security schemes to exist. ${ }^{38}$ In its reasoning thefore, the Court established that it does not affect the power of member states to determine their own conditions. It agreed however with the Commission with regard to the second ground, namely that the the condition requiring a right to reside in the UK gives rise to unequal treatment, namely to indirect discrimination (failing to examine the case of direct discrimination ${ }^{39}$ ) because UK nationals can satisfy it more easily than nationals of the other Member states. ${ }^{40}$ According to the Court, however, it can be justified by a legitimate objective such as the need to protect the finances of the host State, if it complies with the principle of proportionality, and does not go beyond what is necessary to attain the objective. The Court finally concluded that as the verification is not carried out systematically by the UK authorities for each claim, but only in the event of doubt, it follows that the contested measure is proportionate. ${ }^{41}$ Surprisingly, the Court decided that it was the Commission's responsibility to show that the checks were disproportionate, or went beyond what was necessary. ${ }^{42}$

The Court thus came to the conclusion that the UK is entitled to apply the 'right to reside' test to claimants for child benefit and child tax credit which suggests that the line of the German cases discussed above, is now not only extended to special non- contributory benefits which are categorised as social assistance within the meaning of the free movement directive, but also to certain social security benefits under the Social Coordination Regulation. ${ }^{43}$ Setting aside the examination of the directly discriminatory nature of the test, and accepting automatic exclusions contrary to Brey we can rightly assume that the Court has released Member states from an obligation to apply limitations to social security in a proportionate way. ${ }^{44}$ This also points to the increased discretion of the member states in the field of free movement of economically inactive union citizens, even if the the decision has been adopted in a politically sensitive period, nine days before the UK referendum on EU membership.

In any case, the Commission in its new proposal intends to revise the coordination of social security systems making possible the exclusion of economically inactive citizens from all social benefits, irrespective of their qualification for social assistance or social security. According to the new proposal a Member state may require that the access of an economically inactive person residing in that Member state to its social security benefits be subject to the conditions of having a right to legal residence as set out in Directive 2004/38/EC.

38 Commission v. UK judgment para 67.

39 In Verschueren's view this qualification makes posibble the Court to accept the protection of a host Member state's public funds as justification. VERSCHUEREN, H. Economically inactive migrant Union citizens: only entitled to social benefits if they enjoy a right to reside in the host State. In European Journal of Social Security. Vol.19, No.1 (2017), p. 81.

40 Commission v. UK judgment paras $76-77$.

41 Ibid., para 85.

42 This is a problematic reversal of the burden of proof, which requires the Commission to provide information that is in possession of the UK. O'BRIEN, C. R. The ECJ sacrifices EU citizenship in vain, op. cit., p. 227.

43 MINDERHOUD, P., MANTU, S. Access to social assistance, op. cit., p. $205-206$.

44 This conclusion is more finely phrased by Verschueren who opines that judgment leaves a number of questions unanswered, such as the question regarding the application of a proportionality test when an economically inactive migrant Union citizen claims a social benefit in the host Member state. VERSCHUEREN, H. Economically inactive migrant Union citizens, op. cit., p.81. 


\section{COMMENTS}

These lines of cases have been received as a reversal of the Court's classic position protective of rights of free movement and as a betrayal of some of the Court's main doctrine. Moreover, some of the Commentators described it as a "well-established project of EU citizenship-deconstruction". ${ }^{45}$

Truth to be told, the Court is indeed partially retreating from its "most daring pro free movement stances" ${ }^{46}$ This is well reflected in its Dano judgment from which we can conclude that a Union citizen whose lawful residence in the host country is not based on the Directive itself but on some other EU source, such as the provisions of the Treaty ${ }^{47}$, a European Union regulation ${ }^{48}$ or the more favourable provisions contained in the national legislation ${ }^{49}$ would not be entitled to equal treatment concerning social benefits. Indeed, there is a conspicuous gap between the Court's position in the present cases and the previous cases such as Martinez Sala and Trojani where the Court ruled that an EU citizen, residing legally on the basis of national legislation in the territory of a host Member state could rely on the equal treatment provision.

In some Commentators view the Court's narrowly employed test of legal residence, under which a Union citizen can claim equal treatment only if his residence in the territory of the host member state complies with the Directive and the shift we note in the case law- from asking for social assistance being an indication of lack of resources to becoming a certainty that no longer requires an individualised examination of the case- may even lead to an effective exclusion of most economically inactive EU citizens from free movement. ${ }^{50}$

First, we must keep in mind however, that free movement has always been subjected to limits and conditions. The recent jurisprudence of the Court is moving just within this framework laid down by the EU Treaty and secondary law. The Directive in its article 24(2) clearly sets out the exceptions to the equal treatment rule: during the first three months of residence EU citizens are not entitled to any social assistance; EU citizens who move in search of employment can be excluded from social assistance for as long as they are looking for a job; and finally, the host Member state is not obliged to award maintenance aid for studies.

This would not be the first case where the CJEU were adhering to the text of the Directive. Let us think of the Ziolkowski ${ }^{51}$ and Dias ${ }^{52}$ cases dealing with the issue of permanent residence or the Förster case $\mathrm{s}^{53}$ which concerned the award of maintenance grants for students who are nationals of other member states.

Second, we must see, that apart from some issues, the ECJ's recent line of case law brought more clarity into the free movement regime which greatly enhances legal certainty. Clear rules in directive have been confirmed as proportionate and thus have not been subjected to an individual as-

45 O'BRIEN, C. R. The ECJ sacrifices EU citizenship in vain, op. cit., p. 240

46 STRUMIA, F. Chronicles of a Troubled Narrative, op. cit., p. 156

47 On Article 45 TFEU (C- 507/12 Jessy Saint Prix. v. Secretary of State for Work and Pensions) or Article 20 TFEU.

48 C- 480/08 Maria Teixeira v Secretary of State for the Home Department, ECLI:EU:C:2010:83, C- 529/11, Alarape and Tijani v Secretary of State for the Home Department, ECLI:EU:C:2013:290.

49 C-456/02 Michel Trojani v Centre public d’aide sociale de Bruxelles, ECR 2004 I-07573, C- 85/96 Maria Martinez Sala v Freistaat Bayern, ECLI:EU:C:1998:217.

50 MINDERHOUD, P., MANTU, S. Access to social assistance, op. cit., p. 206.

51 C-424-425/10, Ziolkowski and Szeja and Others v Land Berlin, ECLI:EU:C:2011:866.

52 C- 325/09, Secretary of State for Work and Pensions. v. Maria Dias, ECLI:EU:C:2011:498.

53 C- 158/07, Jacqueline Förster kontra Hoofddirectie van de Informatie Beheer Groep, ECLI:EU:C:2008:630. 
sessement when applying them. ${ }^{54}$ That was the case in Alimanovic, where the Court suggested that the provisions on worker status retention in Directive 2004/38 themselves provided a sufficiently gradual system itself taking into account various factors characterising the individual situation such that no more proportionality would be required for those falling through the gaps. Similarly in Garcia Nieto, where the claimants could not ask for social assistance during their first three months of stay, as article 24(2) of the Directive is clear on this.

However, in cases where the Directive contains ambigious provisions - such as the case of the right to residence for economically inactive persons before having acquired a right to permanent residence - the issue of legal uncertainty remains. Thus, with regard to economically inactive citizens for stays exceeding three months a proportionality test must always be applied. The Court's judgement in Dano is somewhat contradictory to the aboves, as the Court in its decision has completely waived the application of the proportionality test. However, as Wollenschaleger correctly points out, Dano should not be misunderstood as restoring the economic residence criteria as conditions strictu sensu. Instead, it can be assumed that the absence of social integration could play an important role in the outcome of the Dano case.

Considering the aboves - and in addition to the "generous treatment" of former workers having become unemployed after a period of work of more than one year and the broad understanding of the concept of worker, we can establish that economically inactive persons still enjoy "an albeit limited-claim to social solidarity in the host Member state". ${ }^{55}$

Of course, it is undeniable, that the Court, as Strumia describes "watered down its narrative of transnational rights and blended with the narrative of Member states' discretion". ${ }^{56}$ The most illustrative example of this is the Commission $\mathrm{v}$ UK decision where the Court essentially gave a licence to a member state to discriminate on the ground of nationality.

In the following we will examine briefly the underlying reasons for this restrictive turn in the Court's jurisprudence relating to the free movement of economically inactive EU citizens.

As a starting point, it must be established, that there is a significant difference between the classic position of EU law on the equal treatment of those who are economically active and the integration requirements for other citizens. This is quite understandable since their "constitutional context differs" ${ }^{\text {"57 }}$ significantly. While the free movement rules for economically active citizens have been an integral part of the common market, ever since the original Treaty of Rome, the free movement rules for economically inactive citizens are closely linked to the concept of Union citizenship established by the Maastricht Treaty. We must see however, that there is "nothing automatic in the projection of a legal solution from one policy field to another". ${ }^{38}$ The equality based reasoning behind economic

54 According to Article 24(1) of the the Directive Union citizens who reside on the basis of the Directive enjoy equal treatment with nationals of the host Member state within the scope of the Treaty. However, we must keep in mind, that a series of exceptions are listed in the second paragraph that of Article 24: during the first three months of residence EU citizens are not entitled to any social assistance, EU citizens who move in search of employment can be excluded from social assistance for as long as they are looking for a job. Finally, the host Member state is not obliged to award maintenance aid for studies.

55 WOLLENSCHLAGER, F. Consolidating union citizenship: residence and solidarity rights for jobseekers and the economically inactive in the post-Dano era. In THYM, D. (ed): Questioning EU citizenship. Judges and the limits of free movement and solidarity in the EU. Oxford : Hart Publishing. 2017, p. 190.

56 STRUMIA, F. Chronicles of a Troubled Narrative, op. cit., p. $149-168$.

57 THYM, D. (ed): Questioning EU citizenship. Judges and the limits of free movement and solidarity in the EU. Oxford : Hart Publishing. 2017, p. 121.

58 Ibid. 
market integration can not justify access to social benefits for those who do not work, especially not in such a crisis period that is just sweeping through Europe.

The twist in EU citizenship jurisprudence occurred in a highly special political and economic context when unprecedented numbers of migrants started arriving from the Middle East. The latter highlighted the failure of the EU's mechanisms to deal with such issues which did not favour the overall legitimacy of the Union. What is more, it increased pressure from different political concerns of the individual member states to control migration more effectively blurring the movement within the EU with that from outside. We must see that the debate surrounding the question of free movement is not new; it has been re-ignited periodically, basically all the way through the entire history of European integration. Let us think of the fears concerning the different rounds of enlargement especially the accession of the Central and Eastern European countries. ${ }^{59}$ In periods of economic recession or high internal political tension due to unemployment, the question of restricting the freedom of movement arises almost routinely ${ }^{60}$ The freedom of movement has gained a "symbolic function" if you will, it serves as a sort of external projection of the currently arisen economic, social and political concerns.

The public discourse, rapidly increasing since the enlargements in 2004 and 2007, took a rather explicit and unfriendly turn in some member states from 2013 onwards. In Germany, Austria and Denmark public debates have emerged on the issue of social benefits for economically inactive EU citizens and study maintenance fees. Similarly, child benefits to mobile EU workers attracted a great deal of public attention in the UK and in Austria in spite of their estimated limited economic relevance. As Sadl and Sankari highlight it very well, in the UK mobility overall became a burden per se. ${ }^{61}$

Thus, it is possible to argue that external political pressure is what prompted the Court to change the direction of the citizenship jurisprudence. Member states wanted more discretion to define the fundamental interest of their own societies and keep under control their public spending. ${ }^{62}$ They expected the Court to apply laxer proportionality review to their protectionist measures which limit free movement and individual rights and find them compatible with European law.

However, the external factors such as the change of political climate itself can not be the sole reason of this restrictive turn. The external crisis only speeded up the process which can be briefly described as the crisis of the EU citizenship itself. The introduction of EU citizenship reiterated the "political dream of building some sort of federal Europe, which culminated in the move towards the Constitutional Treaty". ${ }^{63}$ In this respect however, a "general deficit of European constitutionalism" ${ }^{64}$ became apparent in the last decade. This is well reflected by the fall of the Constitutional Treaty. The latter presented the high point of the "integration through law concept" which employed EU law as

59 Due to those fears the fundamental freedom of movement of workers could be subject to limitations during the transitional period.

60 MANTU, S., MINDERHOUD, P. Solidarity (still) in the making or bridge too far?, op. cit., p. 8.

61 SADL, U., SANKARI, S. Why did the Citizenship Jurisprudence Change? In THYM, D. (ed). Questioning EU citizenship. Judges and the limits of free movement and solidarity in the EU. Oxford : Hart Publishing, 2017, p. 106.

62 With the accession of the Western Balkan countries political fears will intensify due to the massive migration preassure expected from this region. GELLÉRNÉ LUKÁCS, É. The challenges of free movement of persons in the Western Balkan context. In EU Business Law Working Papers, No.2 (2018), p.7. Gellérné Lukács É. - Illés S. Migrációs politikák és jogharmonizáció. 2005. KSH NKI, Budapest.

63 THYM, D. The Evolution of Citizens' Rights in Light of the European Union's Constitutional Development. In THYM, D. (ed): Questioning EU citizenship. Judges and the limits of free movement and solidarity in the EU. Oxford : Hart Publishing, 2017, p. 126.

64 Ibid. 
an instrument for political and social change. ${ }^{65}$ As a building stone of this project Union citizenship was destined to be a fundamental status, the most significant means of expanding belonging within the EU. The main purpose of the idea of Union citizenship was to enhance the mobility of member state citizens within the EU while also contributing to the emergence of a common political and symbolic space. However, the symbolic achievements have not developed so quickly: although the idea of EU citizenship was aimed at promoting a supranational identity based upon common cultural values and political symbols, it has not yet succeeded in superseding and replacing member states' national identities, which "remain preeminent compared to what is still considered a supranational and thus secondary, alternative of belonging". ${ }^{66}$

This is well demonstrated by empirical studies ${ }^{67}$ aimed to compare the sense of belonging to Europe between movers and stayers. These studies show that citizens either do not use their rights or do not identify with the supranational polity when doing so. ${ }^{68}$ As it is pointed out by Recchi intra EU mobility and individual transnationalism remain minority phenomena and this puts a brake on their culturally integrating effects. ${ }^{69}$

Thus, an underlying reason for the more recent retrogression of Union citizenship may be the inherent limits to what an institutional practice of integration through law can achieve. Union citizenship is traditionally conceived as a tool of constitutional engineering which fosters the link between the integration project and member state citizens. However, we must see that citizenship is not a self-fulfilling prophecy. "Treaty changes, new legislation and innovative court judgments alone are not capable of creating an enhanced degree of pan- European identity or solidarity: they need to be embedded into social and political structures" ${ }^{70}$ Union citizenship itself can not justify access to social benefits for those who are ecnonomically inactive and seeks to rely on member states' social welfare system.

\section{CONCLUSION}

This study aimed to analyse case law relating to the entitlement of economically inactive EU citizens to social rights. The Court in Brey found that the right to reside test should not result in the automatic exclusion of economically inactive persons from entitlement to benefits without assessment of their individual circumstances. However, in judgments following Brey the proportionality principle has been completely set aside by the Court. This is acceptable in cases which deal with particular categories of migrants, such as former workers and jobseekers whose individual situation is already taken into account by the Directive itself. In this respect, the new approach is highly welcomed as it brings more clarity in the free movement regime. However, in cases where the Directive contains

65 Ibid.

66 PEREZ, A. M., FUEMTES, F. J. M. Dealing with loopholes in national and EU citizenship. In GUILD, E., ROTAECHE, C. G., KOSTAKOPOULOU, D. (ed): The reconceptualization of European Union citizenship. Leiden, Boston : Brill publisher, 2014, p.150.

67 RECCHI, E. Cross-state mobility in the EU. In European Societies. Vol.10, No.2 (2008), p. 197 - 224.

68 Surveys show that those exercising their free movement rights are inclined to be more supportive of EU integration.

69 RECCHI, E. The engine of Europeanness? In THYM, D. (ed): Questioning EU citizenship. Judges and the limits of free movement and solidarity in the EU. Oxford : Hart Publishing, 2017, p 148.

70 THYM, D. The Evolution of Citizens' Rights in Light of the European Union's Constitutional Development, op. cit., p. 126. 
ambigious provisions - such as the case of the right to residence concerning economically inactive citizens for stays exceeding three months - the issue of legal uncertainty remains. It is undeniable, that a slight change can be observed in the Court's recent case law, at least concerning the increased discretion of the member states in the context of the residence rights of economically inactive citizens. However, we must keep in mind that unlike free movement rules for economically active citizens which are rooted in the Treaty of Rome, free movement rules for economically inactives are linked to the concept of Union citizenship. This concept was destined to be a link between the integration project and member state citizens by the traditional method of integration through law. The new approach of the Court signals a kind of departure from its earlier attempts at constituitional engineering by means of enhanced citizens' rights which can even be conceived as a shift to a "more confederal understanding of the European integration". ${ }^{71}$

\section{Bibliography:}

GUILD, E., ROTAECHE, C. G., KOSTAKOPOULOU, D. (ed): The reconceptualization of European Union citizenship. Leiden, Boston : Brill publisher, 2014, p.149 - 166.

KRAMER, D. Short-term residence, social benefits and the family, an analysis of case C-299/14 (Garcia Nieto and others). Available at <https://europeanlawblog.eu/tag/c-29914-garcia-nieto-and-others/> [q.2018-09-12].

MANTU, S., MINDERHOUD, P. Solidarity (still) in the making or bridge too far? In Nijmegen Migration Law Working Papers Series. Vol.1 (2015), p. 1 - 28.

MINDERHOUD, P., MANTU, S. Access to social assistance. In THYM, D. (ed): Questioning EU citizenship. Judges and the limits of free movement and solidarity in the EU. Oxford : Hart Publishing, 2017, p. $191-208$.

O' BRIEN, C. R. The ECJ sacrifices EU citizenship in vain: Commission v UK. Case C-308/14 Commission v UK Judgment of the Court (First Chamber) of 14 June 2016 EU:C:2016:43. In Common Market Law Review. Vol. 54, No.1 (2017), p. 209 - 244.

PEERS, S. Don't think of the children! CJEU approves automatic exclusions from family benefits in Case C-308/14 Commission v UK. Available at <http://eulawanalysis.blogspot.com/2016/06/dont-think-of-children-cjeu-approves.html> [q.2018-09-12]

PEREZ, A. M., FUEMTES, F.J.M. Dealing with loopholes in national and EU citizenship. In GUILD, E. ROTAECHE, C. G., RECCHI, E. Cross- state mobility in the EU. In European Societies. Vol.10, No.2 (2008), p. 197 - 224.

RECCHI, E. The engine of Europeanness? In THYM, D. (ed): Questioning EU citizenship. Judges and the limits of free movement and solidarity in the EU. Oxford : Hart Publishing, 2017, p. 135 - 148.

SADL, U., SANKARI, S. Why did the Citizenship Jurisprudence Change? In THYM, D. (ed): Questioning EU citizenship. Judges and the limits of free movement and solidarity in the EU. Oxford : Hart Publishing, 2017, p. $89-110$.

STRUMIA, F. Chronicles of a Troubled Narrative. In THYM, D. (ed): Questioning EU citizenship. Judges and the limits of free movement and solidarity in the EU. Oxford : Hart Publishing, 2017, p. 149 - 170.

THYM, D. The judicial deconstruction of Union citizenship. In THYM, D. (ed): Questioning EU citizenship. Judges and the limits of free movement and solidarity in the EU. Oxford : Hart Publishing, 2017, p. 1 - 16.

THYM, D. The elusive limit of solidarity: residence rights of and social benefits for economically inactive Union Citizens. In Common Market Law Review. Vol. 52, No.1 (2017), p.17 - 50.

THYM, D. The Evolution of Citizens' Rights in Light of the European Union's Constitutional Development. In THYM, D. (ed): Questioning EU citizenship. Judges and the limits of free movement and solidarity in the EU. Oxford : Hart Publishing, 2017, p. $111-134$.

71 Ibid., p. 128. 
THYM, D. Legal framework for EU immigration policy. In HAILBRONNER, K., THYM, D. (ed.): EU Immigration and Asylum Law. Commentary, 2nd edition. München, Oxford, Baden Baden : C.H. Beck/Hart/Nomos, 2016.

VERSCHUEREN, H. Preventing benefit tourism in the EU. A narrow or broad interpretation of the possibilities offered by the ECJ in Dano? In Common Market Law Review, Vol. 52, No.2 (2015), p. 363 - 390.

VERSCHUEREN, H. Free movement of benefit tourism. The Unreasonable burden of Brey. In European Journal of Migration and Law. Vol.16, No.2 (2016), p. 147 - 179.

VERSCHUEREN, H. Economically inactive migrant Union citizens: only entitled to social benefits if they enjoy a right to reside in the host State. In European Journal of Social Security. Vol.19, No.1 (2017), p.71 - 82.

WOLLENSCHLAGER, F. Consolidating union citizenship: residence and solidarity rights for jobseekers and the economically inactive in the post-Dano era. In THYM, D. (ed): Questioning EU citizenship. Judges and the limits of free movement and solidarity in the EU. Oxford : Hart Publishing, 2017, p. 171 - 190

\section{Contact information:}

Laura Gyeney, associate professor

gyeney.laura@jak.ppke.hu

Péter Pázmány Catholic University

Faculty of Law and Political Sciences

28-30 Szentkirályi street

1088

Budapest

Hungary 